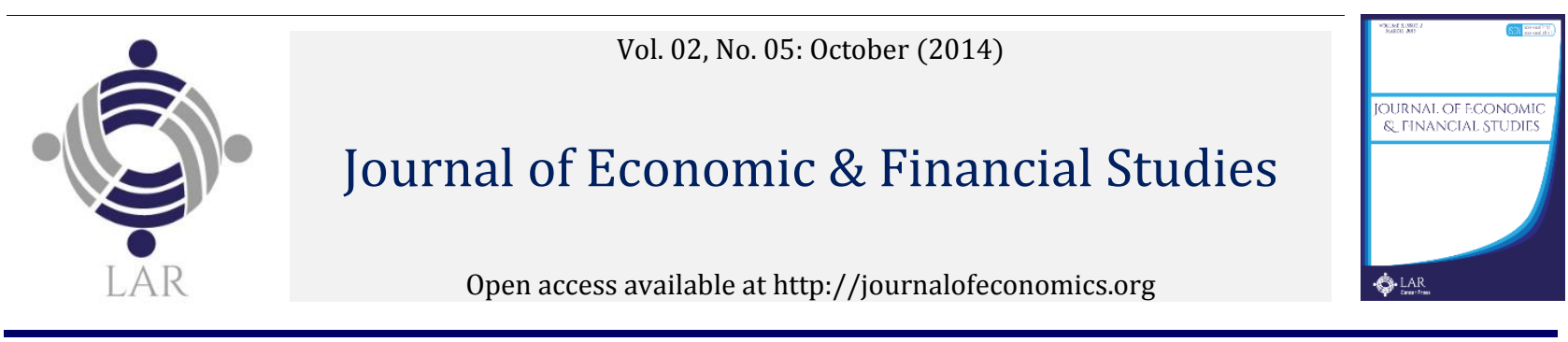

\title{
Bank failures and mergers in Turkey: 1992-2014
}

\author{
Meral Varish Kiefera ${ }^{*}$ \\ a Department of Economics, Cornell University, Ithaca, NY 14850, US. \\ b Faculty of Management, Sabanci University, Istanbul, Turkey \\ *Corresponding author's email: meral999@aol.com
}

H I G H L I G H T S:

1. This study examines the process of bank failures and mergers and acquisitions in Turkey.

2. The study finds that pre-crisis reforms in Turkish banking regulation were effective.

3. In Turkey bank's default probabilities are declining nonlinearly with capitalization for the sample dataset.

4. A semi-parametric survival model is applied to Turkish banking data to confirm the findings.

\section{Article History}

Received: 25-08-2014

Accepted: 11-10-2014

Available online: 24-10-2014

Keywords:

Bank crisis;

Bank policy making;

Capitalization;

Duration model;

Mergers \& acquisitions (M\&A).

JEL Classification:

G01; G21; G34.

allows use, distribution and reproduction in any medium, provided the original work is properly cited.

\subsection{Introduction}

The world of financial institutions is changing rapidly as new risk management techniques are developed and as supervisors worldwide manage the transition to the Basel II and Basel III supervisory standards and subsequent revisions. In this paper, we build an econometric bank default prediction model based on bank specific financial ratios during 1992-2014. A duration model is used to determine the financial ratios that are associated with bank failures and mergers in the Turkish financial markets.

We examine the banking system during the pre-crisis period, crises and subsequent recovery period with emphasis on the implications of banking reforms on the recovery. The time to bank failure event is investigated by analyzing bank indicators in determining the process of bank defaults and mergers. We also examine the impact of bank policy to determine the likelihood with which banks exited through failure, merger, or acquisition under the $\operatorname{SDIF}^{1}$ banks during 1992-2014. Using a comprehensive data set, we apply a duration 
model to link bank-specific data with each bank's risk of failure. While there were 68 private commercial banks in 1999, this number decreased to 18 commercial banks as the results of failures or mergers and acquisitions by 2003. SDIF took over 19 banks, 12 banks merged, 5 banks sold, 3 banks' license withdrew and 3 banks under legal procedure and 9 banks were under SDIF at the end of 2003. As of February 2014, there are 48 banks in total; 31 commercial banks, 13 investment banks and 4 participation banks. ${ }^{2}$

Our aim is to develop a model capable of identifying potential problem banks and vulnerabilities of the banking system, and which could be used by supervisory authorities to inform policy. Since banking crises can generate serious disruptions of economic activities, a main concern of policy makers and regulators is to ensure the safety and soundness of the banking system and prevent the occurrence of banking crises. The role of market discipline in ensuring financial stability is becoming so prominent that the New Basel Capital Accord developed by the Basel Committee on Banking Supervision in 2004. It has included market discipline as one of the three pillars. Although there is extensive literature on the forecasting of banking crises using balance sheet information of banks as well as macroeconomic indicators, studies on prediction of banks defaults using duration model are still novel.

Semi parametric methods are used in this study which allows measuring the effect of bank specific explanatory variables bank failure or default process with duration dependence effects. The capitalization ratio and profitability ratio are the major indicators for measuring banks performance. At the same time, the Basel Committee Accord (Basel Committee on Banking Supervision 2004) requires that banks and supervisory and regulatory authorities consider the capital ratio of the banks they regulate and impose minimum requirements.

A hazard rate and survival model provides a good statistical and econometric tool for banks default and failure prediction in emerging markets. Cox (1972), Kiefer (1988) and Lancaster (1990) developed the semi parametric proportional hazards model. Kiefer (1988) and Lancaster (1990) used duration models in labor economics. Lane \& Ansley (1986), Weelock \& Wilson (2000), and Whalen (1991) are applied duration models to detect financial distress in US banking sector. Barr \& Siems (1994) studied the link between bank management quality and bank failures. Maggiolini (2005) used survival analysis to study the probability of defaults for the novo cooperative credit banks in Italy during 1990-2000. Andersen (2008) investigated the risk index for Norwegian banks. Gepp \& Kumar (2008) used survival analysis to predict business failures. Arena (2008) investigated bank failures for Latin America and East Asia during the nineties. Mannasoo \& Mayes (2009) searched macroeconomic and structural indicators to explain bank failures in Eastern Europe during 1995-2004.

There have been a few studies that investigated time to bank failure using duration models after financial distress in emerging countries. Gonzalez-Hermosillo et $\mathrm{Al}(1996,1997)$ modeled bank failures after the Mexican crisis in 1994. Peek (1995) and Molina (2002) applied a proportional-hazard model to explain time to bank failure during the 1994-1995 Venezuelan banking crisis. Carree (2003) did a hazard rate analysis of Russian commercial banks in 1994-1997 crises. DeYoung (2003) applied hazard and logit on bank distressed in the US in 1980-1985. Canbas (2005) used parametric models with another parametric approach, principal component analysis.

Estrella \& Peristiani ( 2000) and Van den Heuvel (2004) showed that capital ratio is a major risk indicator for financial firms during crises times. Gomez-Gonzalez \& Kiefer (2009) found the capitalization ratio played a crucial role as a explanatory variable to detect the failure of financial institutions in Columbia's economy. Tatom \& Houston (2011) applied to predict the bank failures by using the CAMEL method during 20062010 and 1988 and 1994. Avkiran \& Cai (2012) used a DEA logit with a fully specified CAMELS besides financial market information as credit rating. They identified distressed banks up to two years ahead. Cole \& White ( 2012) reported that large banks have been found less likely to fail than smaller banks. Fiordelisi \& Mare (2013) focused on the contribution of efficiency to cooperative bank probability of default and the survival analysis.

We proceed by giving a brief overview of the banking sector and its dramatic reform in the three decades following the 1999 crisis in sections 2-4. Section 5 briefly reviews merger activity and the effects of foreign direct investment. Section 6 notes the effects of the Basel international capital accord. Section 7 introduces the data, the methods of analysis, summary statistics including survivor functions, and the final estimation results. Implications for the tradeoff between return on investment and default risk are presented in section 8. Section 9 concludes.

\subsection{Banking crisis and restructuring}

${ }^{2}$ Participation banks collect funds through participation accounts and make loans. 
Turkey went through a banking crisis 1999-2001. This led to restructuring and a series of reforms which strengthened the system. As a result, Turkish banking was only mildly affected by the global financial crisis of 2008-2009. We review these reforms briefly.

\subsection{Banking in the 1990s}

For the banking sector in Turkey, the pre-crisis period was characterized by weak transparency, supervision and risk management. The Undersecretary of the Treasury (the Turkish Treasury) and the Central Bank of Turkey were the supervisory authorities under the 3182 Bank Act. The Saving Deposits and Insurance Fund (SDIF) was the Turkish version of the FDIC and took over problem bank management. There was a weak monitoring program and a watch list on problematic banks. Permanent examiners were appointed to evaluate closely the risk assessments of the potential risky banks. During this period, the supervisory authorities were not independent, well structured or encouraged by the governments to take serious steps against the problem banks.

In 1994, a minor banking crisis occurred as a result of macro economic instabilities and banking sector problems $^{3}$. Bank runs happened due to the loss of confidence caused by a sharp depreciation of Turkish Lira versus US Dollars from 0.0144 in 1993 to 0.0384 in 1994. Banks continued to operate in a very risky environment and take high risks to make profits. Banks faced substantial risks in their interest rate exposures with maturity mismatches. They had problems in high foreign exchange position, liquidity and potential loan losses. For instance, within 1994, total loans and receivables to total assets fell by 28 percent and shareholders equity declined by 35 percent. Shareholders equity to total assets ratio downed to 8.5 percent in 1994 from 9.4 in 1993. Net working capital to total assets plunged from 2.2 percent in 1993 to 0.5 in 1994. Non-interest income to non-interest expenses ratio diminished from 15 to -11.3 percent. However, the banking sector recovered quickly after three risky banks ${ }^{4}$ were taken over by SDIF. The Government implemented insurance scheme was applied to all savings deposit holders to stop the panic within the banking system.

In the pre-crisis period, under pressure from the IMF as well as public demand and potential EU membership preparation, the 4398 Bank Act was enacted in June 1999 by the Parliament. This Act partially applied international standards; providing full independence to the Banking Regulation and Supervisory Agency, transferring the authority for licensing, regulating and auditing of banks to the Agency, tightening the related group loans-capital relationship, and accelerating the procedure to deal with financially trouble banks. Based on the 4398 Bank Act, the Banking Regulation and Supervision Agency(BRSA), the Turkish version of the US Office of Comptroller Currency(OCC), was established legally in 1999 and started its activities in 2000. Like the US OCC, the BRSA's goals are safety and soundness.

In August 1999, a catastrophic earthquake hit Adapazari, near Istanbul, 15,000 people dead. The earthquake absorbed the attention and resources of the government. This combined with weak Ecevit's coalition governments $^{5}$ slowed the structural reforms and solving macroeconomic problems; high inflation with 70 percent, high government deficit and high external and internal debts. Therefore, the banking system struggled with the problems of inadequate capitalization, poor asset quality, extreme exposure to market risk, high level of credit risk and operational risk and lack of risk management, responsible corporate governance, independent auditing, transparency, and extensive fraud and corruption.

The most important reason for the high level of risks was the bad influence of the macro economic imbalances on both economic activity and behaviors of economic units ${ }^{6}$. The public sector borrowing requirements caused the real interest rates for short maturities to rise up to 30 percent. This situation caused the losses of the state-owned banks to reach record levels, and the cash flow and liquidity of the banks weakened. Turkish Lira depreciated over 150 percent against US Dollar.

\section{$2.2 \quad$ Banking and Economic Crises: November 2000 and February 2001}

The banking and economic crises happened in November 2000 and February 2001. Market confidence disappeared. Interest rates dramatically rose. The crises occurred as a result of macroeconomic and political instability ${ }^{7}$ as well as banking sector's structural problems. In particular, state banks domination

\footnotetext{
${ }^{3}$ Inflation rate was 121 percent in 2014, GNP declined by 26 percent. Capital outflow reached to 4 billion US Dollar.

${ }^{4}$ These banks were Marmara Bank, Impexbank and TYT Bank operated as commercial banks.

${ }^{5}$ The coalition consisted of the Democratic Left Party(DSP) of Bulent Ecevit as Prime Minister with Motherland Party(ANAP) of Mesut Yılmaz and the Nationalist Movement Party(MHP) of Devlet Bahçeli.

${ }^{6}$ Interest rates on domestic borrowing increased owing to the rise in the public sector's borrowing requirement since external borrowing remained limited in result of the low country rating. Together with the contraction in economic activity reducing demand for loans, the high and chronic inflation effect on the financial condition was seen in the second half of 1998.

${ }^{7}$ The inflation rate (CPI, annual average) was 64.9 percent in 1999, 54.9 percent in 2000 and 54.4 percent in 2001. Interest rate for
} 
caused the market distortion in the sector. The mag- nitude of these crises forced the Ecevit coalition government to face Turkey's economic problems, including fiscal mismanagement, and the need to undertake structural reforms in many sectors including banking.

As of the end of 1999, there were total 81 banks operating in the Turkish banking sector. Of these, 62 were commercial banks, and 19 were development and investment banks. Of the commercial banks, 4 were stateowned, 31 were privately-owned, 19 were foreign banks, and 8 were banks in the SDIF. Of the development and investment banks, 3 are state-owned banks, 13 are privately-owned banks, and 3 are foreign banks.

During 1992-2000, the capital ratios figures ${ }^{8}$ in the banking sector shows that there was a clear deterioration in the financial conditions of the banks. Capital ratios plunged from 9.34 percent to 8.39 percent in 1994 owing to financial meltdown in 1994 mainly caused by short liquidity and foreign exchange exposures as well as fundamental economic problems. Capitalization of banks was corrected to 8.92 percent relatively again in 1996. However, it worsen to 5.87 in 1999, 7.32 in 2000. It back to 9.0 percent at the end of 2001. Net working capital to total assets ratio decreased from 2.34 in 1996 to -0.71 in $1999,-1.23$ in 2000 and -3.6 in 2001. Foreign currency as a fraction of shareholders' equity increased dramatically from 50.60 percent in 1996 to 362.73 in 1999 and realized at 212.23 in 2000. This ratio that showed the foreign currency exposure became more risky. Assets in Turkish currency fell from 61.8 percent in 1993 to 54.8 in 1994. However, assets in foreign currency increased from 38.2 in 1993 to 45.2 percent during 1994 mini crises. The ratio for foreign currency liabilities jumped from 37 percent in 1992 to 46.8 in 1994 as TC liabilities decreased from 63.0 percent in 1992 to 53.2 in 1994. While non-performing loan(NPL)s as a ratio of total loans was at around 2 percent in 1996 and subsequent years, it increased continuously from more than 7 percent in 1998 to 10.72 in 1999 and to 11.52 in 2000 and 19.9 percent in 2001.

\subsection{Banking restructuring and rehabilitation}

The Banking Regulation and Supervision Agency(BRSA) had been tested with these crises and had managed to clean up the sector and recover banking sector confidence. Under the established rules, BRSA went into banking restructuring and rehabilitation. The program consisted of four levels; namely, the restructuring of state banks, the resolution of banks in receivership, the strengthening of private banks and implementation of the new legal and regulatory requirements under the Basel, IMF Program and EU requirements throughout whole banking system.

The first step was to restructure the state banks and adopt a program to eliminate short term funding needs. Overnight liabilities of the state banks were decreased, foreign currency open positions were reduced and new capital was provided to state banks by the Treasury. For example, as a state bank, Emlak bank ${ }^{9}$ was a mortgage bank, which built and sold houses to public at reasonable prices. Since there was no private mortgage financing in the economy, the governments supported low and middle incomes home buyers through Emlak Bank. Emlakbank was politicized, mismanaged and corrupted over time so that increasing losses became a real problem in the banking sector. Emlakbank was transferred to Ziraat bank, the biggest agricultural state bank as of May 31, 2001.

\subsection{Bank intervention and resolution}

The most dramatic intervention is receivership; a complete takeover by the SDIF after referral from the BRSA, like the US OCC handing a problem bank to the FDIC. After the restructuring and strengthening of the state banks, full attention was given to the private banks. First, BRSA forced all banks to stop a number of unsound practices immediately. The BRSA established a comprehensive monitoring and auditing system for all private banks especially focusing on of the control of their exposures to liquidity and interest rates risks. SDIF took over 20 private banks between 2001 and 2003. By 2002, only 2 banks were left in the hands of the SDIF. SDIF banks' overnight liabilities which were USD 5.2 billion decreased to USD 0.8 billion within two months. Some of SDIF banks were sold or merged with more solvent bank(s) or forced into liquidation. All defaulted or bad assets of SDIF banks were transferred to the collection department. The number of commercial banks declined from 81 in 1990 to 53 in April 2003. The total asset size of the mergers and acquisitions that took place in the sector is around 26 billion dollars.

\footnotetext{
Treasury Bills and Bonds was 104.6 percent in 1999, 38.2 percent in 2000 and 99.6 percent in 2001.

${ }^{8}$ Appendices Table 1

${ }^{9}$ Emlak-Eytam Bankası was founded in 1926 and its name was changed to" Emlak Kredi Bankası" on September 1, 1946. It merged with Anadolu Bankası on January 8, 1988. The bank name was changed to Türkiye Emlak Bankası". After the restructuring process by Act ( No 4603) in 2000, it was transferred to"T.C. Ziraat Bankası" with all assets and liabilities as of July 6, 2001. As of July 9, 2001, the headquarter as well as all the branches of T. Emlak Bankası continued their banking activities under the name of Ziraat Bankası. Then, 96 branches of T. Emlak Bank, together with balance sheets and staff were transferred to T. Halk Bankasi on November 12, 2001.
} 


\subsection{The strengthening of private banks}

Each private bank submitted a restructuring business plan covering capital injection, ratio- nalization of branches and personnel, cost reduction and structuring concentrated credits. These were actively followed up on the implementation of such plans within the time limit by BRSA. For instance, Imarbank ${ }^{10}$ was an example of the combination of operational risk ${ }^{11}$ in terms of fraud activities and credit risk ${ }^{12}$ for bad loans defaulted. Imarbank which was a small size commercial bank belonged to the Uzanlar group mostly gave the bank loans to Uzanlar group's companies. The problems of the bank were compounded by differences between reported and non-reported deposit amounts, illegal bond operations and off-shore deposits transferred to domestic deposits.

\subsection{The implementation of the new regulations and accounting rules}

The Capital Strengthening Program encouraged small banks to effect commercially justified mergers and acquisitions. Private commercial banks with an asset market share below 1 percent as of September 2001 could apply for a Tier 1 capital contribution by the SDIF, provided that they meet this threshold through approved mergers or acquisitions. Banks with an asset market share above 1 percent had to apply to the BRSA for approval of mergers or acquisitions by April 30, 2002.

Tax withholding rates on Turkish Lira(TL) deposit accounts were brought down to 14 percent for maturities from 3 to 6 months, to 10 percent for from 6 to 12 months and to 6 percent for those exceeding 12 months. Withholding tax rate on Foreign Exchanges deposit accounts having maturities above one year did not change, but the rate on the accounts with a less than one year maturity was raised from 16 to 18 percent. For repurchase agreements(repo) earnings, the rate was raised from 16 to 20 percent. In fact, many banks survived after restructuring or merging, so public losses were limited. With the changes in the accounting system, banks could prepare balance sheets in line with International Accounting Standards. ${ }^{13}$.

\subsection{Post crisis bank performance (2002-2012)}

After the 2001 banking crisis, banks performance recover dramatically ${ }^{14}$. Non performing loans came under control, reduced as a fraction of total loans from 19.9 in 2001 to 6.6 in 2002, 1.4 in 2003 and continuously decreased to 0.7 in 2004 and 0.3 in 2006. It slightly increased again to 0.7 in 2008 and 0.8 in 2009 due to the global credit crisis. It is realized as 0.5 percent as of June 2012.

Returns on assets improved from -6.6 in 2001 to 1.1 in 2002 and 2.2 in 2003 subsequently; slightly down to 1.4 in 2005 due to the impact of short term international turmoil and recovered to 2.6 in 2007 . As of the end of 2007 and 2008, the Turkish banking system felt deeply the negative effects of the global credit crisis in spite of domestic macro economic stability. Return on assets deceased to 1.8 in 2008 and recovered relatively to 2.4 in 2009 and back to 2.2 in normal range for banking industry. ROE decreased to 1.6 in 2011 and it is realized 0.9 as of September 2012. The non-performing loans are under control, reduced dramatically as a fraction of the total assets since the crises. Banking supervisory authorities are stricter and general provision is over 80 in average. Hence, net non-performing loans are almost insignificant.

\begin{tabular}{|c|c|c|c|}
\hline \multicolumn{4}{|c|}{ Table 01: Percentile (1999-2012) } \\
\hline Banks & \multicolumn{3}{|c|}{ Percentile } \\
\hline & 25 & 50 & 75 \\
\hline
\end{tabular}

\footnotetext{
10 T. Imar Bankasi was founded as a privately owned deposit bank in 1928. The license of T. Imar Bankasi to perform banking activities and accept deposits was revoked upon the Resolution (No.1085) of BRSA, on July 3, 2003, pursuant to Article 14/3 of the Banks' Act No. 4389, due to the fact that the Bank could not timely fulfill its obligations, that it did not take the required measures, and that continuation of its banking activities would have posed a danger to depositors' rights as well as the safety and soundness of the financial system. The Court decided the bank to bankruptcy on June 8, 2005.

11 Operational risk is a new risk category under Basel II. It is defined rather imprecisely as BCBS (2006) para644; the risk of loss resulting from inadequate or failed internal processes, people and systems or from external events.

${ }^{12}$ Credit risk is a form of financial risk that is economic loss from default on a loan.

13 The preparation of consolidated financial statements is related to International Accounting Standards (IAS27). The application of consolidated prudential supervision/reporting requirements based on the models from developed markets. One of the major difficulties faced Turkish banks in preparing consolidated financial statements was the accounting policy differences between banks and non-bank financial institutions. To identify significant inconsistencies between the current accounting policies for banks and non-bank financial institutions(particularly brokerage firms, insurance companies financial leasing companies and factoring companies). To bring the existing consolidation rules for banks in line with International Accounting Standard 27 (IAS27 Consolidated Financial Statements and Accounting for Investments in Subsidiaries), an analysis was performed of the discrepancies between IAS27 consolidation requirements and current consolidation rules for banks.

14 See Appendices Table 2.
} 


\begin{tabular}{crrr}
\hline Cap & 10.07 & 14.58 & 32.84 \\
Income & 0.16 & 1.08 & 2.25 \\
Loan & 17.72 & 40.73 & 51.64 \\
Obs & 104.85 & 199.71 & 357.28 \\
Size & 3.42 & 13.28 & 82.88 \\
\hline
\end{tabular}

Net income to total asset called "Income" is shown by quartile over time in Figure 1. There is a convergence in performance as uniform standards spread through the sector. The convergence occurs as the industry recovered from 2000-2001 crisis. The smaller distance between quartiles indicates probably increasing competition and efficiency in banking.

Capitalization (Cap) is defined here as the shareholder's equity over total assets and is graphed in Figure 2. It shows that capitalization at the low side gradually increasing over the period. The lowest quartile is over 10 percent. The median reached 17 or 18 percent after the recovery of 2000-2001.The capital ratio was nearly 14 percent in 2008, 17 percent 2009, 16 percent in 2010 and decreased to 14 in 2011 and 2012. The upper quartile varies considerably showing that $\mathrm{th}$ is distribution has a long and changing upper tail.

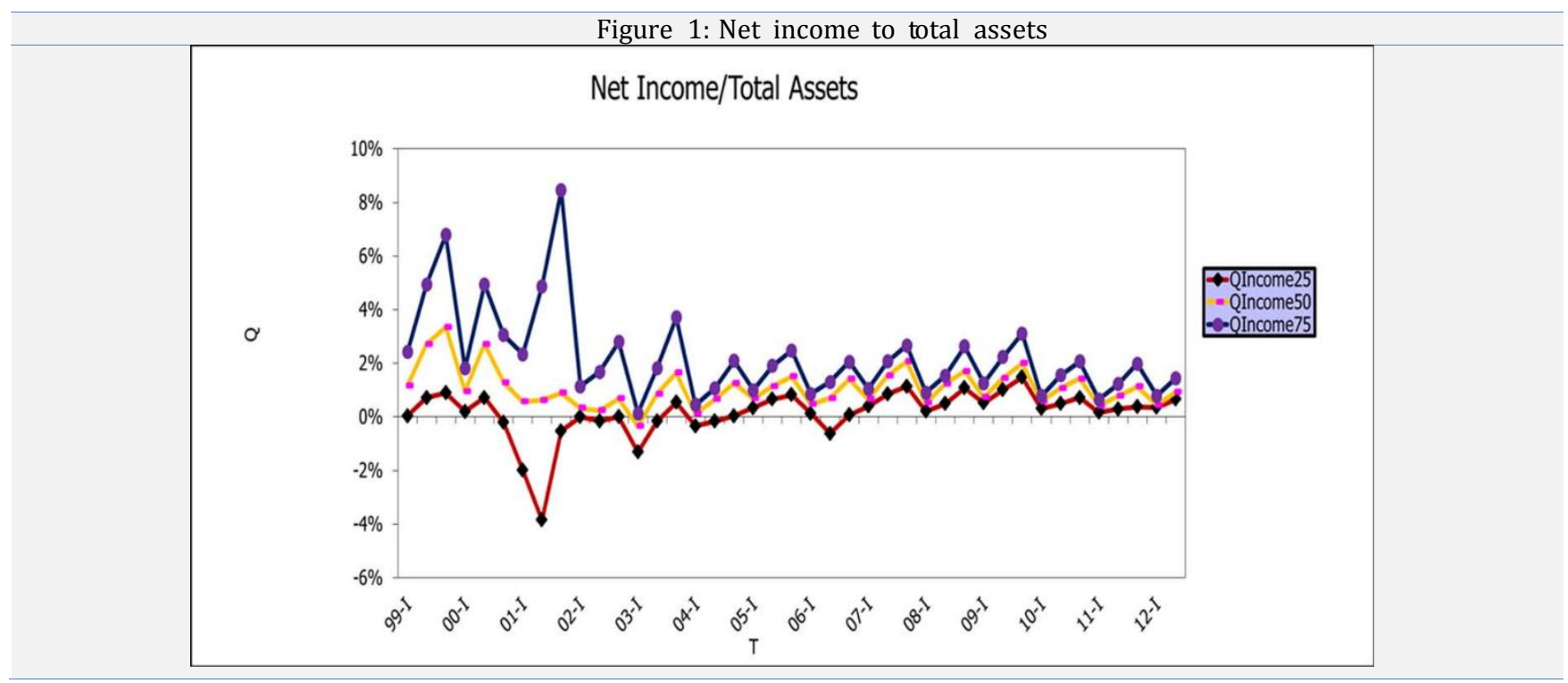

The capital ratio was nearly 20.55 percent in 2001, 48 percent in 2003. 39 percent in 2008 , 42 percent in 2009. It realized 29 percent in 2011 and 25 percent as of June 2012. Therefore, there is some convergence since 2009 as overcapitalized banks reenter the markets.

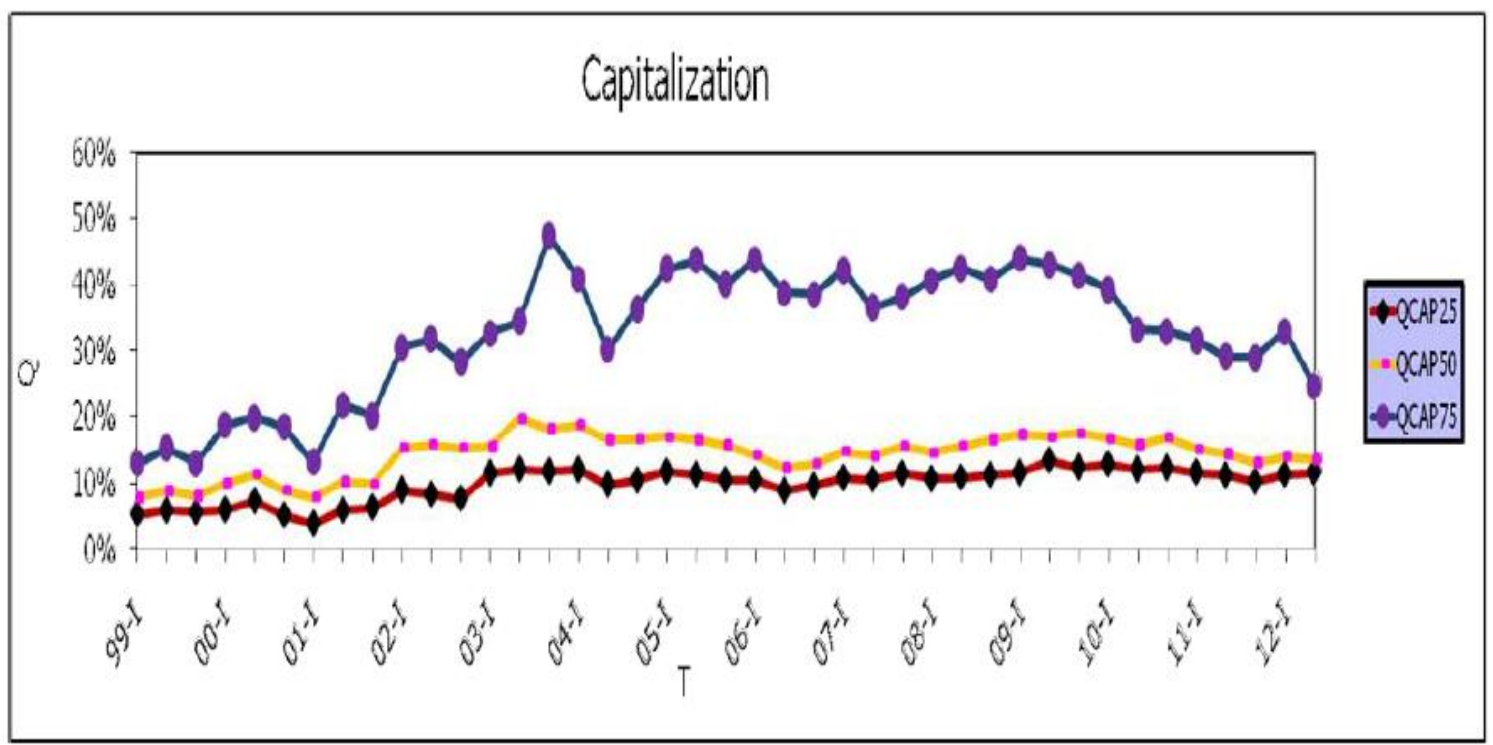


Higher capital could help enhance banks' soundness and stability. However, high capital ratios may imply some weaknesses in their earning capacities. If this happens, then it may take a long time for banks to regain their competitiveness. This prospect may then undermine their soundness and hence weaken their competitiveness further. This competitive disadvantage could become more serious if financial markets are opened up while the financial sector restructuring is in progress.

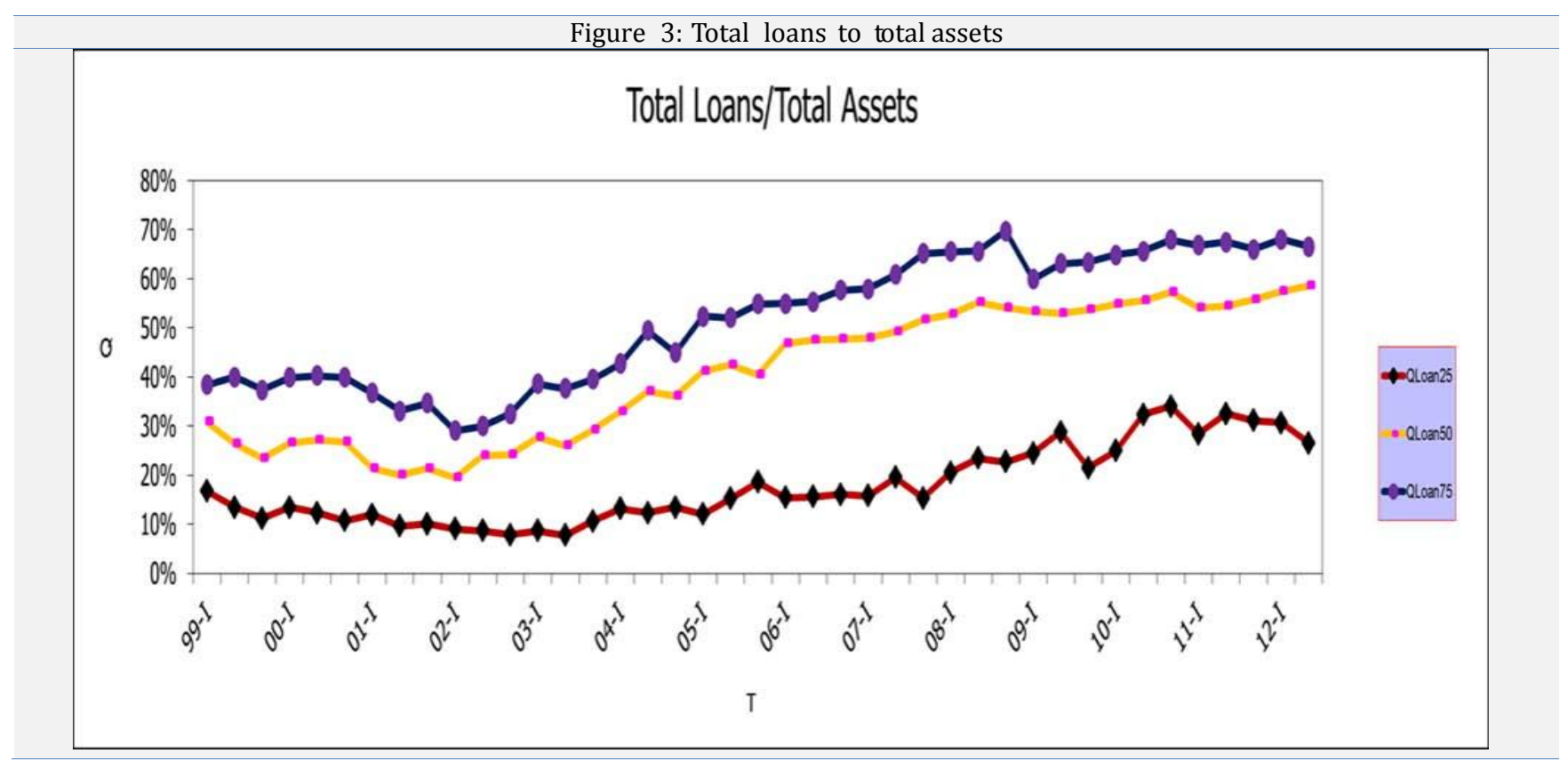

Loans to total assets(Loan) is a crude measure of exposure to credit risk. The quartile graph is Figure 3. This distribution shows a long lower tail; the distance between first and median is much bigger than median and third quartile. It is more spread on the long end; probably some banks do not make loans. Banks are generally increasing their loan activity since 2002. It indicates that banks focus on doing real banking activities that is good for the economy. It can be interpreted that other profit centers such as trading are less associated with the real economic activity.

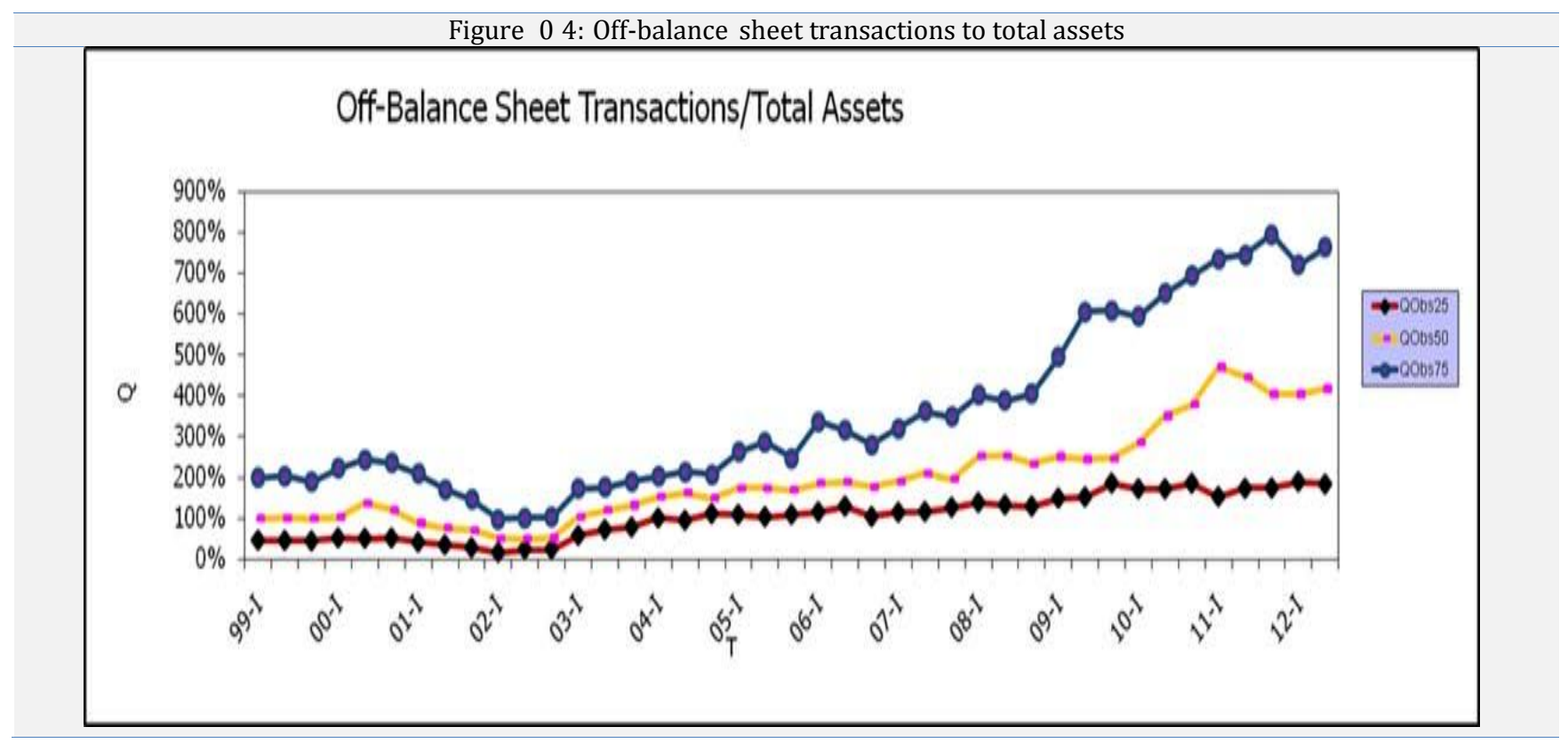

Off balance sheet transactions to total assets is shown in Figure 4, by quartiles. The whole distribution has been shifting up since 2003, probably reflecting increasing hedging and increased foreign currency denominated international activities. It is plausible whether this variable represents increased risk, because of the lack of capital requirements for off- balance sheet activities or decreased risk arising from effective hedging with derivatives.

Size defined as the total assets of the bank divided by by a common number to scale the variable. As shown 
in Figure 5, these are a small number of large banks and more smaller banks.

Figure 05 : Size of the firms

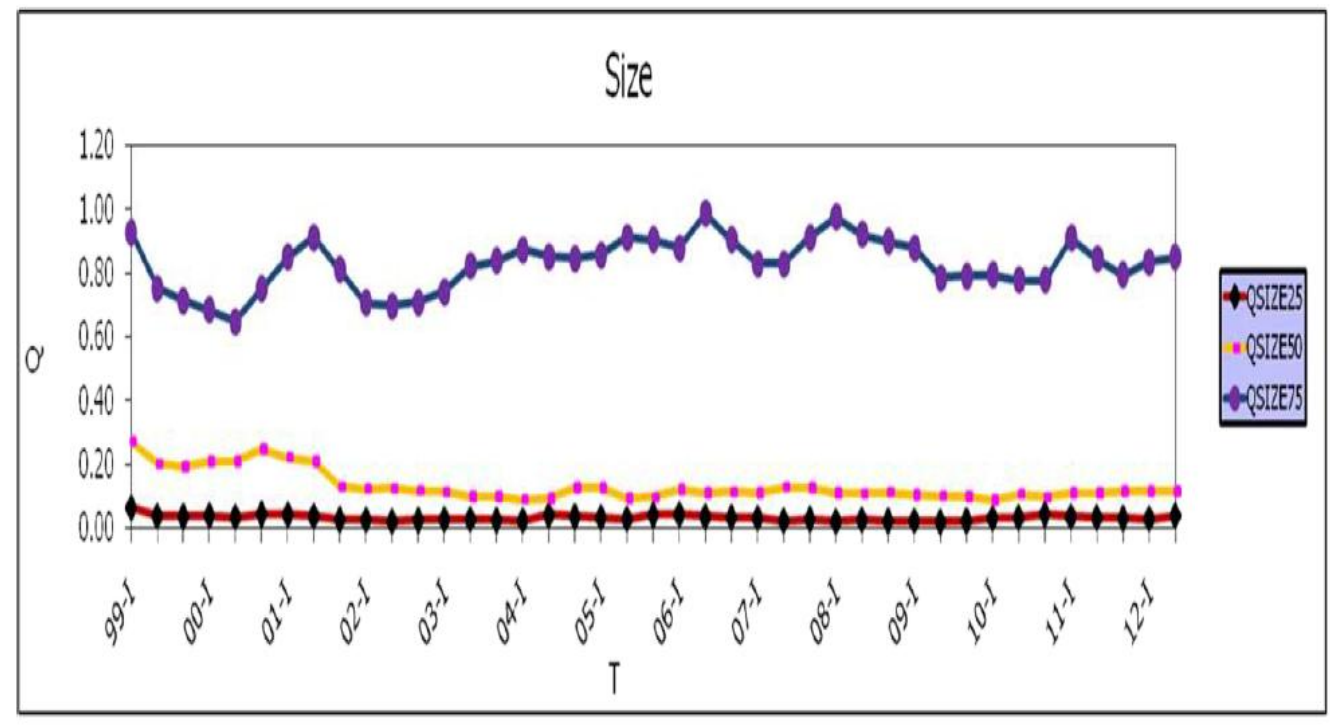

\subsection{Merger and acquisition (MA) and foreign direct investment (FDI)}

Since 2002, banks have been operating in a considerably less risky environment.15 Turkey has achieved macroeconomic stability by following tight monetary and fiscal policies in cooperation with the IMF guidelines. Further, it completed privatization programs and cleaning up the banking sector. Improvement in the banking sector made investments in Turkey more appealing to the international market. Foreign direct investments increased since the recovery. Foreign direct investments soared to 10 billion dollar in $2005,20.2$ billion in 2006, 22 billion in 2007, 19.5 billion in 2008 and plunged to 8.4 billion in 2009 and 9 billion. FDIs reached to 16 billion dollar in 2011 and 12.4 billion US dollars in 2012.

It is clear that the smooth operation of the banking system under the new regulations and risk management contributed significantly to the recovery and to the inflow of international capital. Foreign investors' interest intensified. Table 3 shows the major deals of mergers and acquisitions. The financial institution has the highest level of foreign direct investments with the peaked level to 12 billion in 2007, 6 billion in 2008 and 6 billion dollar in 2011.

\subsection{Basel standards and EU directives}

The Banking Regulatory and Supervisory Agency(BRSA) in 2005 announced the implemen- tation of EU directives and Basel standards ${ }^{16}$. As of July 2011, BRSA accelerated again the adoption Basel II and European Union's standards. In particular, the Basel II process in Turkey has been started as of July 1, $2011^{17}$. However, many biggest commercial banks have been implemented these standards voluntarily to adapt international standards. The standard approach and basic standard approach realized for capital adequacy ratio and calculations of credit risks in 2012. The Advanced Approach have been harmonized by 2013. However, EU's full implementation of Basel II for all member states have been by 2012 for credit risk and market risk. The Advanced approach to operational risk; basic and standardized approach have been implemented as of 2012. After the 2008 global financial crisis, new Basel III regulation has taken placed for strengthen capital requirements and liquidity. Basel Committee on Banking Supervision (2012) focuses on safety and sound supervisory systems in international financial system.

\footnotetext{
15 Turkey completed successfully a three year 10 billion dollars lending accord with the IMF which improved the economy significantly and established strong growth after the 2001 financial crisis. The first AKP(Justice and Development Party(JDP) government in 2003, using all advantages of the economic reform agenda inherited from the Ecevit-Yilmaz and Bahceli coalition government, and the good global economic environment, applied a successful tight fiscal and economic program, making reforms for starting EU accession, accelerating privatization and so attracting foreign direct investments to the country.

16 The Basel II agreement categorized mainly three pillars for capital determination. These are minimum capital requirements; supervisory review, and transparency, leading to market discipline. The minimum capital requirements include three major types of risk: credit risk, market risk, and operational risk.

${ }^{17}$ Like EU authorities, BRSA also declared the postponing of previous 2005 road map due to the negative effects of the 2008 and 2009. global credit crisis on the Turkish banking system.
} 


\subsection{Analysis}

A duration model is used in this study to analyze the time to banks failures and mergers and acquisition in Turkey. This model generalizes the more common binary response logit or probit analysis by modeling the occurrence of failure or merger or acquisition and the time to failure or MA jointly, allowing for covariates and not restricting (much) the duration dependence.

\subsection{Data}

We collected time dependent bank-specific data ${ }^{18}$ between 1992-2014 (quarterly and annually reports) for private and state-owned depository commercial banks, development and investment banks ${ }^{19}$ and foreign banks operated in Turkey between March 1992 and January 2014. We examined financial statements including balance sheets, income statements and statement of cash flows. In line with the literature, we selected bank performance measurement ratios as quarterly time-dependent covariates. We focused on capitalization ratio, loans to total assets, net income to total assets and contingencies to total assets and each banks size ratio(total assets to mean of total assets).

Failure is the event in which a bank is liquidated, either by the decision of BRSA or SDIF or by the decision of the bank management. The moment in which the bank fails is defined as the time in which the bank is liquidated formally; that is, the moment at which the bank stops reporting its financial statements to the BRSA and SDIF. Although this is not a exact measure of the moment in which a bank fails, it appears to be the best possible approximation. Banks that have made decision to merge or were acquired by other financial institution while financially healthy are not considered as failures in this study. It is a failure if it was under a serious financial distress, transfer, merged and sold by BRSA or SDIF to another bank.

Overall, there are 88 banks in the sample, of which 30 banks failed between March 1992 and March 2003 based on the research fails criteria. Of these 30, 25 were commercial banks and 5 investment banks. There were no further bank failures and mergers in 2003-2014. We collected mergers and acquisitions data from the various reports of BRSA, SDIF and Turkish Banking Association and banks official resources. Mergers and acquisitions sample consists of total 67 mergers or acquisitions events between March 1992 and January 2014. Most of the mergers and acquisitions deals were observed as a foreign bank acquisition as which the acquirer is a bank holding company, commercial bank or investment bank or financial institutions, at the same time target Turkish bank is a commercial bank or a investment bank or a bank holding financial services company. We excluded MA deals if a bank was liquidated by SDIF Fund or under the fund management or fails based on the BRSA regulations discussed in above. We also excluded if a foreign seized the operations in Turkey with associated of the any reason. Besides, the sample did not include any mergers and acquisitions deals were not approved or were canceled by BRSA.

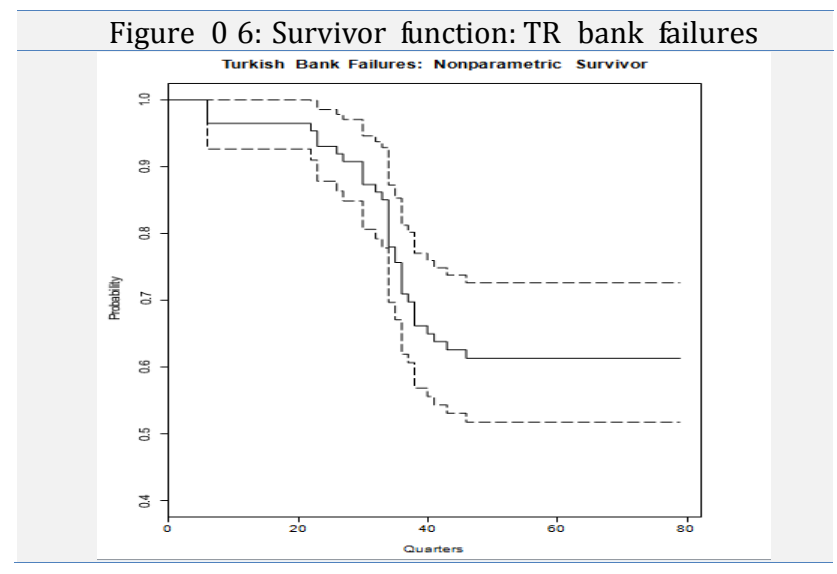

\footnotetext{
${ }^{18}$ Data Sources: Bank Association of Turkey (BAT) and Banking Regulatory and Supervisory Board (BRSA).

${ }^{19}$ Banks in Turkey are classified into two main groups: commercial banks and investment and development banks. By owners, each group can be put into three subcategories: private-owned, state-owned and foreign banks. Commercial banks operate as universal banks providing traditional depository and lending services, financing foreign trade activities and sustaining capital market services as well as investment bank activities. The major differences between commercial banks and investment banks are based on capital, liability composition and size. Investment banks are non- depository financial intermediaries. However, commercial banks accept deposits from customers and also make consumer and commercial loans. Mostly commercial banks' loans are held on the bank's balance sheet as an asset of the bank.
} 
Figure 6 shows the raw survivor functions (non-covariates). Most of the bank failures occur between 1999-2003. The survivor function does not have a exponential distribution which is against using a general model like logit. The dotted lines are the 95\% confident intervals for the estimated survival function. This paper emphasizes some major accounting ratios that are considered in the explana- tion of time to failure and mergers of banks.

Cap: Capitalization defined as the ratio of shareholder's equity to total assets

$\mathrm{Cap}^{2}$ : Quadratic function(non-linearity) square of the capitalization ratio.

Loan: Loans given by total loans over total assets

Obs: Off-balance sheet transactions defined as the ratio of totaloff-balance sheet trans- actions to total assets

P rofit: Income given by the ratio of annualized net income to total assets

InvBank: It is a dummy variable covers only non deposit financial institutions, Invest- ment Banks

Fail : An insolvent bank is liquidated by supervisory or regulatory authority.

Since capitalization is a key ratio for regulators, typically with a minimum regulatory capital requirement, we are particularly interested in this variable. We look for non-linearity, suspecting that the marginal effect of capital is more crucial in reducing default risk when capital is low than when it is high. This would seem to be the logic underlying most regulation. Note that our measure of capital is not quite that used by regulators, who typically use more than equity in the numerator and adjust the denominator for riskiness of different assets. With our data attempting to adjust for riskiness would just add noise. Note that the nonweighted asset figure is that used in calculating leverage limits by some regulators. Further, note in interpreting the results that the risk-weighted capital ratio will be larger than our capital ratio. To account for a non-linearity of capitalization, we added a variable Cap-squared Cap ${ }^{2}$.

\begin{tabular}{|c|c|c|c|}
\hline Variable & Mean & sd & Median \\
\hline Cap & 19.28 & 21.08 & 11.35 \\
\hline Loan & 36.04 & 32.36 & 34.54 \\
\hline Obs & 3657.0 & 44208 & 177.1 \\
\hline P rofit & 3.00 & 27.85 & 1.48 \\
\hline InvBank & 0.29 & - & - \\
\hline F ail & 0.0068 & - & - \\
\hline
\end{tabular}

Table 2 gives the summary statistics. We have also considered other accounting and financial ratios, but these are our focus. The difference between the mean and median in Obs indicated that Obs is concentrated in a few banks, probably specialists in foreign exchange activities. The failure rate is low since the data are reorganized so that each bank/period is an observation. This is to allow time-varying covariates. It is the bank failure probability in a particular period every quarter which is quite small.

\subsection{Survival analysis}

Duration models are widely used to study the time to the occurrence of an event. In the case of bank failure or default, duration is the time that it takes for a bank to fail or mergers and acquisitions activities after the occurrence of a banking crisis that might affect the whole financial system. The Kaplan Meier estimates of the survivor function for the raw data (unadjusted for explanatory variables) is given in Figure 6. The survivor function does not exhibit the geo-metric decline characteristic of the exponential indicating caution in specifying a functional form is appropriate. It is difficult to make a real inference without adjusting for covariates.

\subsection{Explanatory variables and proportional hazard regression}

Our main aim in this empirical study is to understand how bank-specific accounting and financial covariates influenced the conditional probability of default and time to failure and mergers and acquisitions after the crises in the banking system. In ordinary regression models, explanatory variables involve the dependent variable by moving its mean. In duration models, it is not straightforward to see how explanatory variables influence duration and the interpretation of the coefficients in these types of models depends on the particular specification of the model.However, proportional hazard regression is a semi-parametric model that assumes a parametric form for the effects of the explanatory variables but allows an unspecified form for the underlying hazard function with minimal assumptions. The specification for the hazard function (the default probability at the conditional time on survived to time $t$ and covariates $x$ is: 
$\lambda\left(\mathrm{t}, \mathrm{x}, \beta, \lambda_{0}\right)=\varphi(\mathrm{x}, \beta) \lambda_{0}(\mathrm{t})$

Where $\lambda_{0}$ is the baseline hazard. Time-varying covariates enter in an index form $\left(X_{i}(t) \beta\right)$. Note that the effect of time on the hazard rate is captured completely through the baseline hazard. One common specifications for the function $\varphi$, which is followed, is $\varphi(x, \beta)=\exp \left(x^{\prime} \beta\right)$ where $x$ is a vector of covariates and $\beta$ is the coefficient vector. A partial likelihood approach similar to Cox's can be used and the baseline hazard can be estimated. This requires that data have units of observation bank/quarter - so failure is a rare event.

Under this specification for all $\mathrm{k}$.

$\frac{\partial \log (\lambda(.))}{\partial x_{k}}=\beta$

Therefore, the coefficients can be interpreted as the constant, proportional effect of the corresponding covariate on the conditional probability of completing a spell. In the particular case of bank default, completing a spell is associated with the moment in which a bank is liquidated or SDIF intervened to the problem bank or the authority revoke the license of the bank. The index form is potentially restrictive although we explore nonlinear effects by ap- propriate regressors, in particular the square of capitalization. Since the baseline hazard is unrestricted, the model is semi-parametric in that regressors enter as parametric but the un- derlying duration distribution is completely unrestricted. This is very general specification. With the small of data for the low failure rate more general models are not indeed feasible.

\subsection{Maximum likelihood estimation}

We estimated the proportional hazard model using maximum partial likelihood. We use the survivor package Therneau \& Lumley $(2008)^{20}$.

\subsubsection{Estimation result for failure}

We begin by reporting a fit of a linear probability model, noting that this is not an adequate model for this problem; however, that is nevertheless a common first approach, showing that things make sense and providing an easily understood summary of some elementary relationships in the data. We experimented with several specifications and report the simple regression of a binary survive or fail variable on capitalization, net income to assets and dummy variables as investment banks. As expected, capitalization has a negative effect on the failure rate. The net income to assets has a negative effect, puzzling if this variable is interpreted as measuring exposure to credit risk. Perhaps healthier banks make more or better loans.

Figure 0 7: Bank Failures: nonparametric survivor

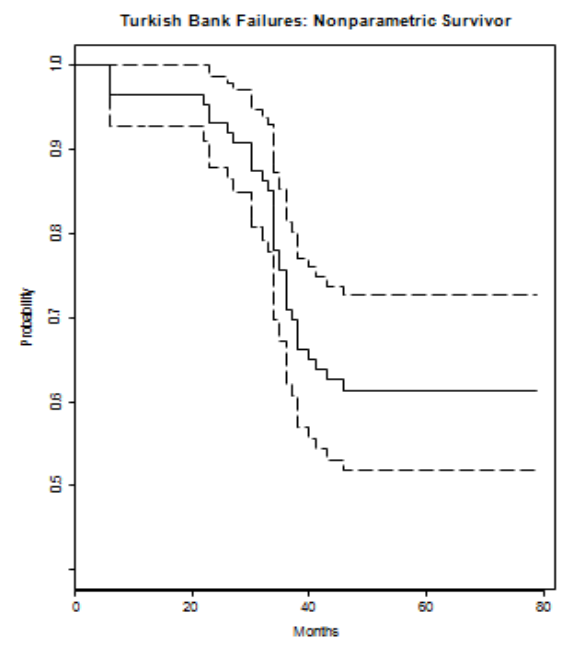

Note that most failures occur during 25-45 quarters period which is corresponding be- tween 1999 to 2003. This survivor function is far from the exponential form which is only suggestive as there is no control for covariates.

${ }^{20}$ Original by Terry Therneau and ported by Thomas Lumley (2008) in R. 


\begin{tabular}{lcc}
\hline & Table & 0 3- Linear model results \\
\hline \multicolumn{1}{c}{ Variables } & Coefficient & Standard Error \\
\hline Intercept & $1.632 \mathrm{e}-02$ & $2.325 \mathrm{e}-03$ \\
Cap & $-1.061 \mathrm{e}-03$ & $1.971 \mathrm{e}-04$ \\
Cap $^{2}$ & $1.141 \mathrm{e}-05$ & $2.317 \mathrm{e}-06$ \\
P rofit & $-8.764 \mathrm{e}-05$ & $4.127 \mathrm{e}-05$ \\
InvBank & $4.772 \mathrm{e}-03$ & $3.027 \mathrm{e}-03$ \\
F Statictics & 8.236 on 4 and $4395 \mathrm{DF}, \mathrm{p}=1.295 \mathrm{e}-06$ \\
\hline Multiple R Squared & \multicolumn{2}{c}{0.006537} \\
\hline
\end{tabular}

The linear model is included only for completeness. Nevertheless, the results are signifi- cant and suggestive; capitalization decreases the failure rate, with a nonlinear effect, namely capital increases are more effective when capitalization is low. It is obvious that profitable banks are less likely to fail.

\begin{tabular}{lcc}
\hline \multicolumn{3}{c}{ Table 0 4: Cox proportional hazard model results } \\
\hline \multicolumn{1}{c}{ Variables } & Coefficient & Standard Error \\
\hline Cap & -0.1214867 & 0.0333819 \\
Cap $^{2}$ & 0.0012487 & 0.0003634 \\
P rofit & -0.0965066 & 0.0211373 \\
InvBank & 0.5088305 & 0.5485916 \\
Log-likelihood test & 44.39 on $4 \mathrm{df}, \mathrm{p}=5.332 \mathrm{e}-09$ \\
Wald test & 50.52 on $4 \mathrm{df}, \mathrm{p}=2.807 \mathrm{e}-10$ \\
Score(logrank)test & 57.22 on $4 \mathrm{df}, \mathrm{p}=1.114 \mathrm{e}-11$ \\
R-squared & 0.01 (max possible $=0.046$ ) \\
$\mathrm{n}$ & \multicolumn{2}{c}{4400} \\
\hline
\end{tabular}

Note that the data are set up in a format with observation equal to bank/time period in order to accommodate time-varying covariates. Consequently the great bulk of observation has no failure and $\mathrm{R}^{2}$ is a highly misleading statistics since there is a little variation around the mean. Therefore, the $\mathrm{F}$ and $\log$ likelihood statistics are more relevant. Turning to the rather more reliable proportional hazard results, we find that the negative effect of capitalization on failure holds up. We also find a non-linearity - under capitalized banks gain more from an increase in capital than well-capitalized banks. The results are not substantially changed for neighboring values. There is a clear non linearity, as shown by the significance of the capitalization variable (these are robust standard errors). Experimentation with a number of other financial ratios and a dummy variable iden- tifying investment banks did not substantially change the results so the simplest model is reported(almost). The loans to total assets variable is insignificant; dropping it does not substantially change the results. It is included since it seems economically compelling as a measure of exposure, thought clearly it could also be a measure of the banks' financial health.

The results from the nonlinear specification show convincingly that the effect of capitalization on the default probability is larger for low values of capitalization (higher default probabilities) and much smaller for higher capitalization. This is consistent with most regulatory policy. The baseline survivor function from the proportional hazard model is given in Figure 8 together with the 95 percentconfidence interval. This is not very precisely estimated, so a variety of functional forms would probably fit equally well. It does not seem to exhibit geometric decline, so the exponential model (underlying some logit analyses) is not likely to be appropriate. Our results, because of the semi parametric formulation with the unspecified baseline hazard, do not depend on a functional form assumption here, but do give significant results on the variables of interest.

\section{Figure 0 8- Baseline Survivor(Fail)CPH-Covariates; Cap,} profit
Figure 0 9- Baseline Survivor(Fail) CPH-Covariates; Cap, profit, deposit 


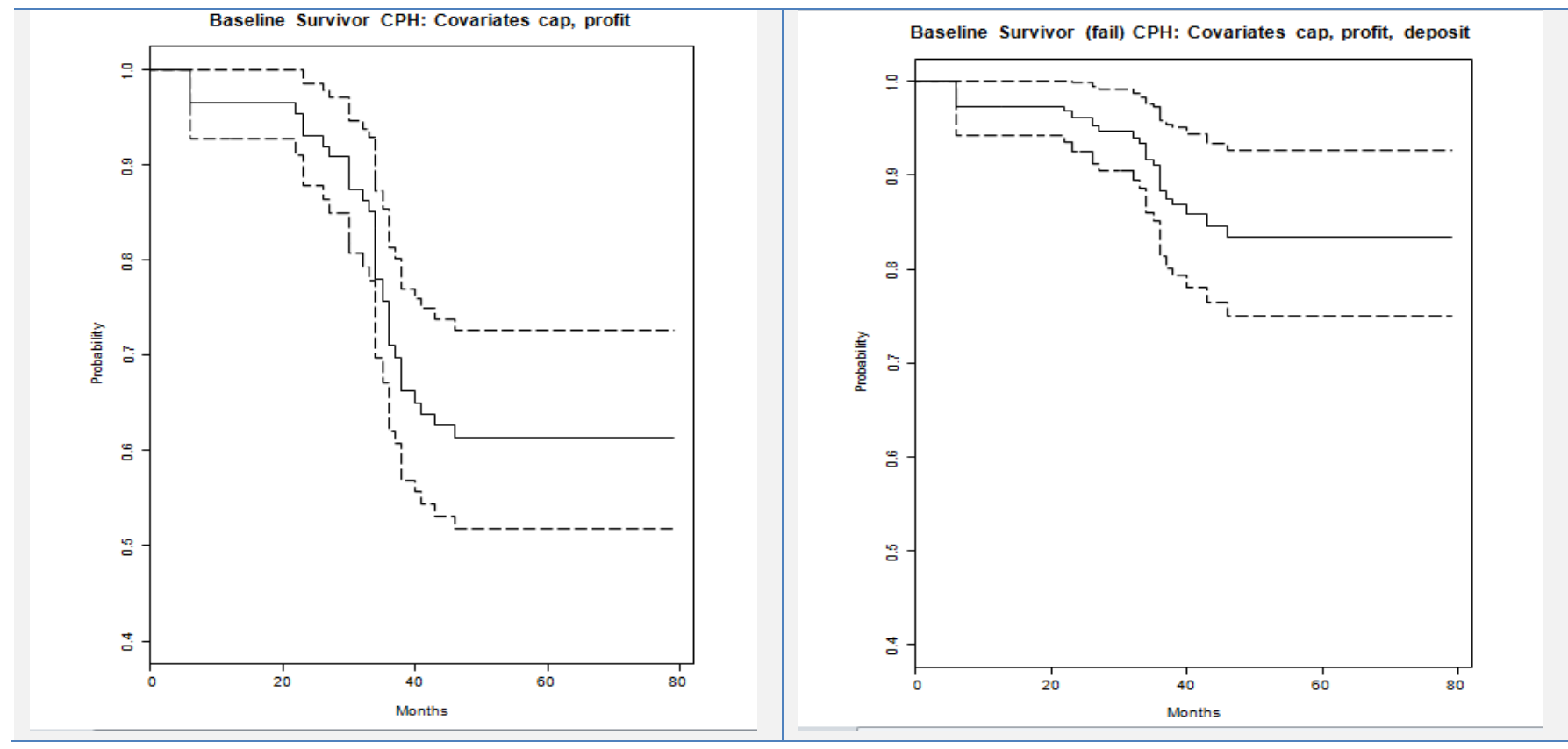

\subsubsection{Estimation result for MA}

There were a large number of mergers and acquisitions following the banking reforms as banks came into compliance with the new requirements. These consisted of both domestic and foreign acquisitions.. Our results show that undercapitalized banks were more likely to be acquired. This is not an obvious result: overcapitalized banks might be seen as a profit source and a way to improve capitalization in the merged bank. In fact, undercapitalized banks in this period were often also unprofitable, indicating probably a problem with management.

\begin{tabular}{lllcc}
\hline \multicolumn{5}{c}{ Table 0 5: Mergers and acquisitions in Turkish banking } \\
\hline \multicolumn{1}{c}{ Acquirer } & Target & Shares (\%) & Value (US\$ M ) \\
\hline Year & HSBC & Demirbank & 100 & 350 \\
2001 & BNP-Paripas & TEB & 50 & 217 \\
2004 & Unicredito & Kocbank & 57.42 & 1,484 \\
2004 & RIBO-JSC(2006) & Sekerbank & 37 & 90 \\
2005 & Fortis & Disbank & 89.34 & 1136 \\
2005 & GE Financial & Garantibank & 25.5 & 1,556 \\
2005 & Unicredito-Koc & YKB & 57.4 & 1,500 \\
2006 & Dexia & Denizbank & 99.85 & 3,253 \\
2006 & Merrill Lynch & Tatbank & 75 & 6 \\
2006 & NBG & Finansbank & 46 & 2,774 \\
2007 & Citigroup & Akbank & 20 & 3,078 \\
2007 & ING & Oyakbank-ING & 100 & 2,673 \\
2007 & Deutche Bank & Garantibank & 100 & 115 \\
2009 & NBG & Finansbank & 9 & 700 \\
2010 & Credit Europe Bank & Millenium Bank & 95 & 85 \\
2011 & GE Capital & Adabank & 100 & 75 \\
2012 & Sberbank & Denizbank(Dexia) & 99.85 & 3,504 \\
\hline
\end{tabular}

As seen Table 5, most of mergers and acquisitions began right after the 2001 crises and intensified until $2007^{21}$.

\footnotetext{
${ }^{21}$ The biggest examples are as follows: Demirbank was transferred to SDIF Fund and sold to HSBC Bank in Turkey. Fortis Bank acquired 89.34 percent of Türk Dış Ticaret Bankası, Türk Ekonomi Bankası(TEB) took over Fortis Bank with all assets and liabilities on January 25, 2011. BNP Paribas indirectly acquired 42.125 percent shares of Türk Ekonomi Bankası on February 10, 2005. Finans Bank signed an agreement to sell 46 percent shares to National Bank of Greece April 3, 2006. National Bank of Greece acquired all shares Koc Bank. Koç Financial Services went the 50/50 joint venture between Unicredit and KoçGroup. The joint venture acquired 57.4 percent share by Yapı ve Kredi Bankası held by the Gukurova Group and SDIF fund.
} 


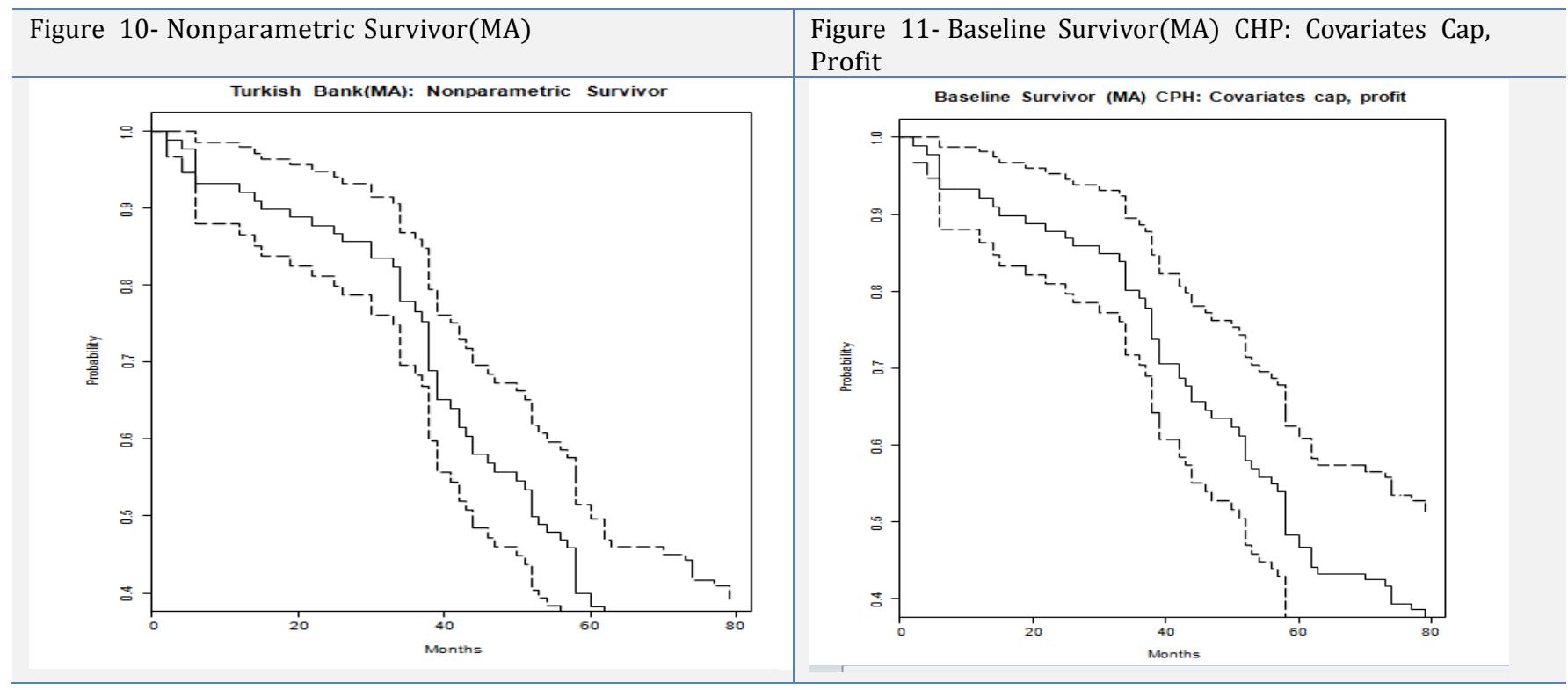

Investment banks works for MA, and is also significant variable. We suppose this means people like to acquire investment banks in Turkey. That $\mathrm{m}$ a k e s sense for an expanding institution; commercial banks provide a stable source of funds.

\begin{tabular}{lcc}
\hline & Table & 0 6: Linear model (MA) result \\
\hline \multicolumn{1}{c}{ Variables } & Coefficient & Standard Error \\
\hline Intercept & $1.608 \mathrm{e}-02$ & $3.739 \mathrm{e}-03$ \\
Cap & $1.527 \mathrm{e}-04$ & $3.171 \mathrm{e}-04$ \\
Cap $^{2}$ & $4.561 \mathrm{e}-07$ & $3.726 \mathrm{e}-06$ \\
P rofit & $-6.575 \mathrm{e}-05$ & $6.637 \mathrm{e}-05$ \\
InvBank & $-1.682 \mathrm{e}-02$ & \\
F Statictics & 3.63 on 4 and $4395 \mathrm{DF}, \mathrm{p}=0.005863$ \\
Multiple R Squared & & 0.002385 \\
F Statictics & 3.63 on 4 and $4395 \mathrm{DF}, \mathrm{p}=0.005863$ \\
\hline
\end{tabular}

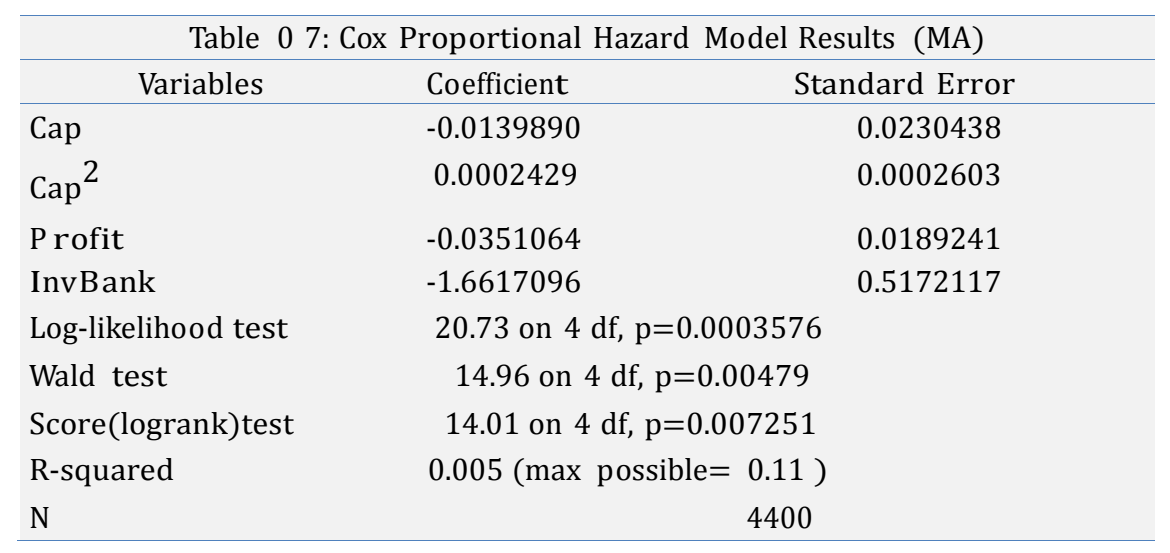

These coefficients make sense; under capitalized banks are more likely to be acquired, as are unprofitable banks (an unprofitable bank can perhaps be acquired a good terms). Specification checks based on Schoenfeld residuals are reported in the appendices and do not indicate problems with the proportional hazard specification.

\subsection{Implications}

Figure 12 shows the nonlinear effect of capitalization on the one-quarter ahead default probability as estimated with the extended Cox proportional hazard model. Increasing capitalization decreases the default probability at a decreasing rate. Current values of capitalization are around 13 percent, indicated on the figure, and the historical regulatory value was 8 percent. 
The estimated-quarterly values are converted to annual values in that the default probability is equal to the expected value about 0.07 for annual default. We used various Cap at the estimated coefficients to calculate the new default probabilities. This shows the estimated relation between capitalization and the annual default rate. The default probabilities are probably too high for the current economy - recall they are based on the cluster of defaults in the 99-02 period. It is that group of defaults, however, that allows estimation of a significant nonlinear relation between defaults and capitalization. The shape of the graph is likely to be still relevant, although the actual plotted rates may be higher than currently relevant.

The key is that the default rate is decreasing in capitalization, and in fact decreasing at a decreasing rate. Thus, the benefits of additional capitalization are higher at lower levels of capital. This is consistent with regulatory policy.

Figure 13 shows a return on equity by capitalization that is an approximation by calculation of ROE. Return on equity is income over equity. The calculation adjust the fraction of assets earning at risk free rate and the rest of capital earned the average return on equity in the sample. Therefore, increasing capitalization decreases the ROE in two ways; 1-By increasing equity by decreasing income 2-Two curves are given in this Figure 13. First (upper high) is ignoring default risk. The second(lower down) curve takes into account of the default risk.

Increasing capitalization decreases the default rate but also decreases the return on equity. We have done an approximate (very approximate!) calculation of ROE (income/equity) by capitalization. This calculation simply adjusts the fraction of assets earning the risk-free rate (assumed zero for this calculation). The rest of capital earns the average ROE. Increasing capitalization thus decreases ROE by increasing equity and decreasing income. There are two curves, one ignores default risk, the other (lower) takes into account that risk with default resulting in a 100 percent loss.

There is an interesting offsetting effect here: at lower capitalization the 1)ROE is higher because of the higher leverage, 2) default risk is higher (from the previous graph), and 3)loss given default is reduced, since the equity is lower and losses are limited to equity since banks are corporations. The total effect is given by the red curve.

A social optimum requires balancing these effects. One hundred percent reserves would eliminate (most) failures, but would be an ineffective social allocation of capital, as capital is buying too much failure protection. Note that all corporations face a failure risk and indeed this is encouraged by the existence of the corporate limited liability form. As a first approximation, we can use our results to examine the return on equity cost of increased capitalization. We take as base values return on equity of 13 percent and return on assets of 2) percent (roughly consistent with recent values). We suppose that increasing equity increases the fraction of assets earning the risk-free rate-assumed to be zero- and decreases the fraction earning the return on risky assets. Obviously there are a lot of approximations here and the results are speculative, but interesting. For example, decreasing equity would doubtless increase the cost of the bank's bond financing, but this is not taken into account at this level of approximation. With these qualifications in mind, Figure 13 gives plots of the return on equity versus the capitalization. One curve (the higher) shows the ROE assuming non- default. This is relevant potentially as there is some speculation that agents under emphasize or ignore very small probabilities. The lower curve plots expected return taking account of the possibility of default and sub- sequent loss of all equity. Both curves show that considerations only of ROE will lead to as low a capitalization as possible. This illustrates the need for regulation, as the investors have only their equity at risk, while society has more through deposit insurance. Our results help policymakers think about the menu of choices available.

As a final summary, we plot the expected ROE vs the failure rate in Figure 14. It shows a kind of menu as ROE and Default Rate pairs that is available by choosing different values of capitalization. This figure combines the cap-failure and ROE-Failure graphs to eliminate failure. This gives the "menu" of ROE-default rate pairs available to a bank. ROE takes account of default. Note again all the approximations involved so the actual numbers should not be taken too seriously. But the shape is sound. This figure is tricky to interpret. Here are some of the considerations:

First, this is the tradeoff from the point of view of the bank. The social trade-off, relevant to regulators, is different. In particular, the social loss given default is larger for society than for the bank. To see this, note that the corporate form (designed to encourage risk taking) limits losses to shareholders. They can lose their equity and no more. On the other hand, if a commercial bank fails, depositors will lose some fraction of their deposits. This is a social loss. This is true whether it is covered by deposit insurance or not: the point is, someone incurs a loss, perhaps depositors, perhaps taxpayers, perhaps the population of bank 
customers if losses are covered by insurance paid for by all banks as in the US.

Second, ROE, of interest to some investors and some regulators, is not the same as the present value of the stream of income associated with the investment. If a bank fails, ROE is -100 percent during the period of failure. Income attributable to that equity goes to zero and remains at zero for all future periods. So, focusing on ROE may understate the actual value of the losses to shareholders, depending on their investment horizon. Third, when one bank fails in isolation, the figure is relevant (subject to the warnings above). When many banks fail the losses are compounded as the financial system is com- promised. This is a concern of regulators, not the individual bank.) But what does the figure say? 


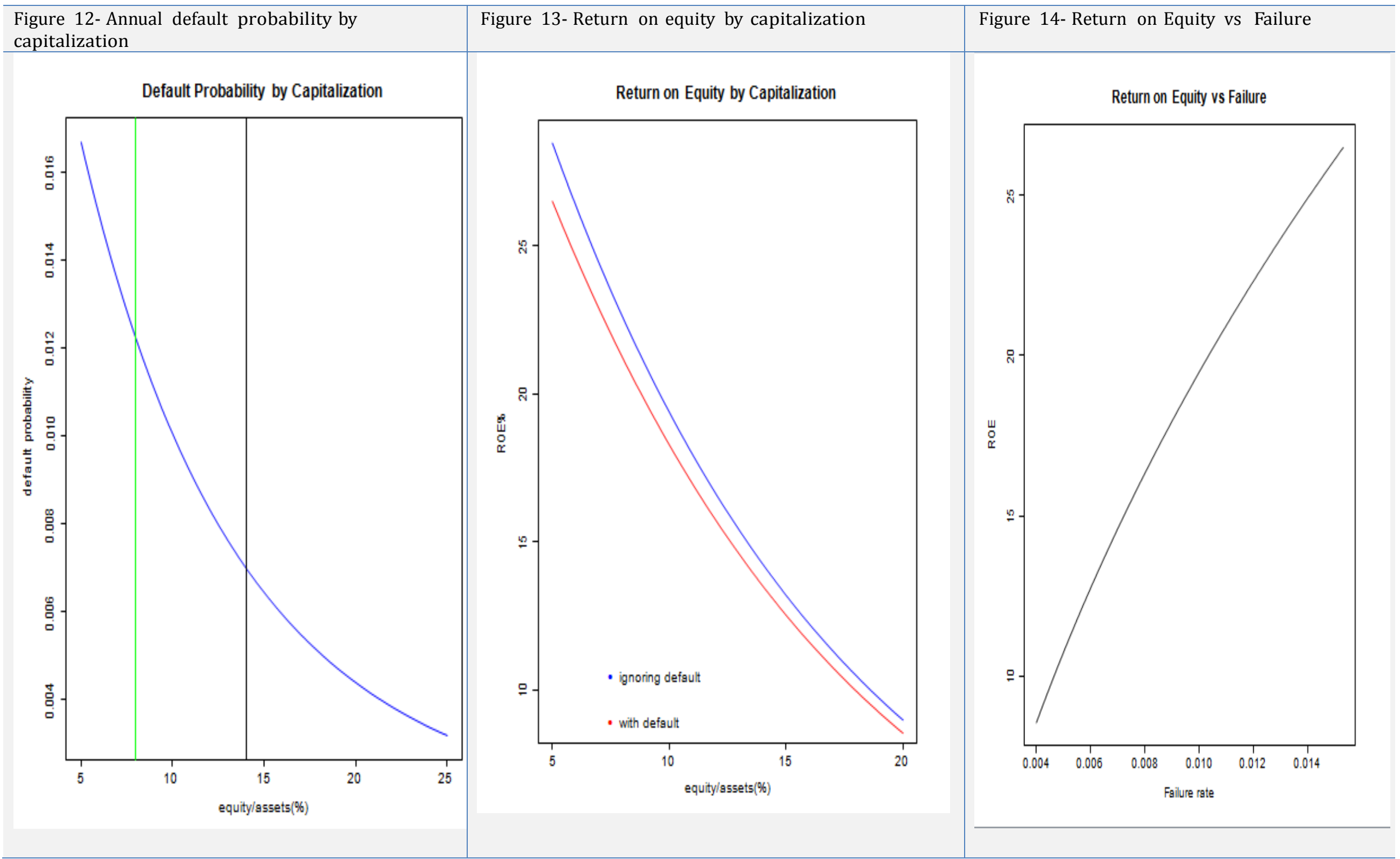


From the bank's point of view, risk taking is attractive, due in large part to corporate limited liability, which shifts risk away from the bank and to depositors and other counterparties. Hence, regulation is necessary from a social point of view. From the regulators point of view, allowing additional default risk decreases the amount of capital necessary to support the financial system, thus releasing capital for other productive uses. On the other hand, the additional default risk could lead to more frequent crises than a highly capitalized system. A richer country can afford more safety and Turkey is now "buying" more safety. Choosing the right point on the tradeoff is tricky. But calculations like these can help guide the discussion.

\subsection{Conclusions}

We have studied the default rate in the Turkish banking system during the tumultuous period of 19922012. Our focus was on estimating the effect of capitalization, the principle regulatory tool, on failure. We use a semi-parametric model for estimation so that the conclusions on capitalization will not be affected by potential specification error in duration dependence. Our results provide evidence against the exponential failure model implicitly underlying a number of specifications previously implemented. We find that, at low levels of capitalization, increasing capitalization substantially reduces the risk of default. At higher levels of capitalization, the marginal effects of capitalization on defaults are much smaller and not statistically significant. Thus, minimum capital requirements seem to be a sensible tool. Too little capital is associated with a higher default risk. At high levels, increasing capital does not change the (low) default rate but will, of course, reduce profitability. This is the tradeoff that must be managed by banking authorities. Our examination of MA show that under-capitalized institutions are less profitable and the $\mathrm{s}$ banks are more likely to be acquired. This is not an obvious result: over-capitalized banks will be less profitable typically and therefore ripe for acquisition and new management. Finally, we make a rather speculative calculation of the implied tradeoff between the default rate and the return on capital. This relationship is increasing in the relevant range, as expected, but we are able to add empirical content to the social choice problem.

\section{References}

Andersen, H., 2008. Failure prediction of Norwegian banks: A logit approach. Norges Bank Working Paper 2.

Arena, M., 2008. Bank failures and bank fundamentals: A comparative analysis of Latin America and East Asia during the nineties using bank-level data. Journal of Banking \& Finance, 32: 299-310.

Avkiran, N. K. \& Cai, L. C., 2012. Predicting bank financial distress prior to crises. Working Paper.

Barr, R. S.; Seifors, L. M. \& Siems, T. F., 1994. Forecasting bank failure: A non-parametric frontier estimation approach. Working Paper.

Basel Committee on Banking Supervision 2004. International convergence of capital mea- surement and capital standards: A revised framework, Technical report, Bank for International Settlements.

Basel Committee on Banking Supervision 2012. Core principles for banking supervision, Technical report, Bank for International Settlements.

Canbas, S., \& Cabuk, K., 2005. Prediction of commercial bank failure via multivariate statistical analysis of financial structures: The Turkish case. European Journal of Operational Research, 166(2): 528-546.

Carree, M., 2003. A hazard rate analysis of Russian commercial banks in the period 1994-1997. Economic Systems, 255-269.

Cole, R. A., \& White, L., 2012. Deja vu all over again: The causes of US commercial bank failures this time around. Journal of Financial S e rvi c es Research, 42: 5-29.

Cox, D., 1972. Regression models and life-tables. Journal of the Royal Statistical Society, B34: 187-220.

DeYoung, R., 2003. De novo bank exit. Journal of Money, Credit, and Banking, 35(5): 711-728.

Estrella, A.S.P., \& Peristiani, S., 2000. Capital ratios a s predictors of bank failure. Economic Policy Review, 6: 33-52.

Fiordelisi, F., \& Mare, D.S., 2013. Probability of default and efficiency in cooperative banking. Journal of International Financial Markets, Institutions and Money, 26:30-45.

Gepp, A., \& Kumar, K., 2008. The role of survival analysis in financial distress prediction. International Research Journal of Finance and Economics, Issue 16: 13-34.

Gomez-Gonzalez, J., \& Kiefer, N.M., 2009. Bank failure: Evidence from the Colombian financial crisis. The International Journal of Business and Finance Research, 3: 15-31.

Gonzalez-Hermosillo, B., Pazarbasioglu, C., and Billings, R., 1996. Banking system fragility: Likelihood versus timing of failure: an application to the Mexican financial crisis. IMF Working Paper.

Gonzalez-Hermosillo, B., Pazarbaşioglu, C. and Billings, R., 1997. Determinants of Banking System Fragility: A Case Study of Mexico. Staff Papers - International Monetary Fund 44: 295-314.

Kiefer, N. M., 1988. Economic duration data and hazard functions. Journal of Economic Literature, XXVI: 646679.

Lancaster, T., 1990. The Econometric Analysis of Transition Data. Cambridge University Press. 
Lane, W. S. L., \& Wansley, J., 1986. An application of the cox proportional hazards model to bank failure. Journal of Banking and Finance, 10: 511-531.

Maggiolini, P., \& Mistrulli, P. E., 2005. A survival analysis of de novo co-operative credit banks. Empirical Economics, 30: 359-378.

Mannasoo, K., \& Mayes, D. G., 2009. Explaining bank distress in Eastern European transition economies. Journal of Banking \& Finance, 33(2): 244-253.

Molina, C., 2002. Predicting bank failures using a hazard model: The Venezuelan banking crisis. Emerging Markets Review, 3: 31-50.

Peek, J., Rosengren, E., 1995. Bank regulation and the credit crunch. Journal of Banking and Finance, 19: 679692.

Schoenfeld, D., 1982. Partial residuals for the proportional hazards regression model. Biometrika, 69(1): 239241.

Tatom, J., \& Houston, R., 2011. Predicting failure in the commercial banking industry. Networks Financial Institute, Working Paper No. $2011 / 27$.

Therneau, T., \& Lumley, T., (2008) S original survival: Survival analysis, including penalised likelihood, R package version 2 .

Van den Heuvel, S., 2004. The Bank Capital Channel of Monetary Policy. Wharton School University of Pennsylvania.

Weelock, D., \& Wilson, P., 2000. Why do banks disappear? The determinants of U.S. bank failures and acquisitions. The Review of Economics and Statistics, 1: 127-138.

Whalen, G., 1991. A proportional hazards model of bank failure: An examination of its usefulness as an early warning tool. Economic Review, 27: 21-30. 